\title{
Human Rights in Orthodoxy and Islam A Comparative Approach
}

\author{
ADRIAN BOLDIȘOR*
}

In a world where increasingly more voices from different geographical areas talk speak about equality between people, religions are called to uphold and preach human dignity and rights of all people, without taking account of race, sex or religion. In the interreligious dialog, the meetings between representatives of Christianity and Islam have multiplied considerably and they deal with themes analyzing preaching and defending human rights at all levels of life. From the preceding discussion it is clear that the human rights issue is quite sensitive, especially after the latest political, economic and social events that have shaken the world in which we live. After the period of time that the proclamation and recognition of global human rights were made as contained in the various international documents, it was passed into a new phase where the followers of different religions should work together for human dignity and human rights.

Keywords: human rights, Orthodoxy, Islam, pluralistic world, ecumenical dialog, modernity, minorities, liberties, equality, freedom

\section{Introduction}

In a world where increasingly more voices from different geographical areas talk speak about equality between people, religions are called to uphold and preach human dignity and rights of all people, without taking account of race, sex or religion. In this climate the promotion of interreligious dialogue is a constant nowadays, given the profound transformations that occur in the whole world, whether political, economic, social or religious. So, in the context of globalization that characterizes humanity in our century, the dialogue between religions prevails in the agendas of world leaders. In this dialog the meetings between representatives of Christianity and Islam have multiplied considerably and they deal with themes analyzing preaching and defending human rights at all levels and at all levels of life.

\section{Human rights in the modern and contemporary time}

In the Middle Ages one cannot speak of the promotion of human rights in the way of equality between people, regardless of race, sex or reli-

Revd. Adrian Boldişor, PhD Assistant Professor at the Faculty of Orthodox Theology, University of Craiova, Romania. Adress: Str. Potelu, nr. 150, bl. R 15, sc. 1, ap, 1, Craiova, Romania; e-mail: adi_boldisor@yahoo.com 
gion. Even the most popular documents from this period, among which is highlighted the Magna Carta from 1215, do not seem to contain traces of future formulations of human rights as they are known today. The beginnings of modern discussions proposing embodied solutions in documents signed by the participants in the various meetings that have discussed the issue of human rights are found in the eighteenth century. This century, called "The Century of Lights", had a strong secular individual and bourgeois tinge and what can be easily seen in the statements that have been preserved. Though, these characteristics led to their rejection by representatives of many religious traditions ${ }^{1}$, especially since, in the meetings in which documents were issued, not all the world religions were represented although the proposed solutions are desired to be available for all people regardless of the religious tradition to which they belong.

Among the international documents that speak of universal human rights, an important place is occupied by the thirty articles of the Universal Declaration of Human Rights adopted in Paris by the United Nations General Assembly on 10 December 1948. This Declaration led to a number of global agreements among which are International Covenant on Civil and Political Rights and the International Covenant on Economic, Social, and Cultural Rights, both from 1966. Parallel to and in close contact with it are the American Declaration of Independence on 4 July 1776 and The Declaration on the Rights of Man and Citizen according to the French National Assembly in 26 August 1789.

These statements, although they have different philosophical bases, are similar in the essence of the formulation of human rights. Thus in England, a bill was formulated defending human rights in 1689 based on class differences. Between 1776 and 1789 America=established human rights in its Constitution with the underlying fight for freedom against the bourgeoisie. It also happened in France in 1789, where French rights were based solely on rationalist philosophy. " "Human» rights were juxtaposed to the «divine» rights of monarchs, the traditional recipients of the church's patronage. This was a major reason why Roman Catholic and Orthodox teaching as well as most Protestant theology on the European continent rejected the notion of human rights, preferring instead to emphasize human duties". ${ }^{2}$

\footnotetext{
David Little, "Human Rights and Responsibilities in a Pluralistic World" in: Emmanuel Clapsis (ed.), The Orthodox Churches in a Pluralistic World. An Ecumenical Conversation, WCC Publications, Geneva-Brookline-Massachusetts 2004, p. 77.

2 Erich Weingärtner, "Human Rights" in: Nicholas Lossky, José Míguez Bonino et al. (eds.), Dictionary of the Ecumenical Movement, WCC Publications, Geneva 2002, p. 548.
} 
Rights of the working class were formulated against bourgeois rights, promoted by Marx and Engels and applied mainly in Russia after the Revolution of 1917 . The twentieth century is characterized by the struggle against colonialism and promoting rights of communities more than human rights ${ }^{3}$, with an emphasis on promoting peace on earth. Finally, the issue of human rights has become one of international interest. The United Nations enacted The Universal Declaration of Human Rights on 10 December 1948, providing a strong link between the desire for world peace and defence of the natural rights of man. Human connection and equality were thereby emphasized; all people, regardless of their religion, have the same rights. From the starting point in the middle of the last century, the organizations promoting human rights have increased both locally, nationally and globally. Human rights as formulated are intended to be recognized as universal, having certain common characteristics: they are inviolable; they claim freedom, proclaim equality and involve the participation of people in decision-making together. ${ }^{4}$

At about the same time the European Convention on Human Rights came into force in 1950; it had great importance in promoting and protecting human rights. Those who do not follow this convention must be held accountable by an institution called the European Court of Justice for Human Rights in Strasbourg. Such institutions have been formed over time on other continents, which demonstrate a growing concern regarding the protection of human rights worldwide. Among the rights contained in the European Convention on Human Rights are: right of life; prohibition of torture or inhumane or degrading treatment or punishment; prohibition of slavery and forced labour; right to liberty and security of person and regulation of circumstances of arrest and detention; right to fair and public trial, and the presumption of innocence until proved guilty; decision of guilt and punishment in terms of the law applicable at the time and place a criminal act was committed; right to respect for private and family life; freedom of thought, conscience and religion; freedom of expression; freedom of peaceful assembly and association; right to marry; right to an effective recourse to a national authority for victims of violation of these rights; prohibition of discrimination in these rights on grounds of sex, race, colour, language, religion, etc.; limitations on the right of national government to withdraw rights in times of war or national emergency; permission for governments to restrict the political activity of aliens; prohibition of use of these rights for the purpose of destroying them;

$3 \quad$ Ibidem, p. 549.

4 Ibidem. 
prohibition of using stated restriction to rights for any purpose other than that stated. ${ }^{5}$

In our times, the top five documents about human rights are the International Bill of Human Rights: Universal Declaration of Human Rights (December 10, 1948), International Convent on Economic, Social, and Cultural Rights (December 16, 1966; into effect January 3, 1976), International Covenant on Civil and Political Rights (December 16, 1966; into effect March 23, 1976), Optional Protocol to the International Covenant on Civil and Political Rights (December 16, 1966; into effect March 23, 1976), Second Optional Protocol to the International Covenant on Civil and Political Rights, aiming at the abolition of the death penalty (December 15, 1989). Alongside these are other statements that refer to the defence and promotion of human rights, which means that this problem concerns the whole world. ${ }^{6}$

At the same time we must not forget the fact that after 1948, when the World Council of Churches was founded, the actions of promoting and protecting human rights by organizing meetings that took this work theme on agendas have intensified. Similar actions were undertaken by the World Union Lutheran and Reformed churches of the 1970s, and also by the Catholic Church, especially the declaration Dignitatis Humanae in 1965, during the Second Vatican Council.

Finally, one can establish three essential features of human rights as formulated in the international declarations by which most countries around the world are guided: high standards, universal validity and equality of freedom. In a careful analysis of how human rights are formulated all these statements can be concluded that: "the character of human rights as legal rights imposes limitations on their normative claim. An indication of these limitations is important precisely in terms of the inter-religious or intercultural debates, although observations continue to be expressed to the effect that human rights are portrayed as a modern, global «humanitarian religion», calculated to repress or even replace traditional religions or cultures. If human rights are understood as standards of political rights, such observations can be discounted. Human rights make no attempt to substantiate comprehensive claims in terms of religion or worldview. They offer no answers to existential questions regarding the meaning of human life and death; they make no pronounce-

\footnotetext{
Jorgen S. Nielsen, "Human Rights in the West" in: Tarek Mitri (ed.), Religion and Human Rights. A Christian-Muslim Discussion, WCC. Office on Inter-Religious Relations, Geneva 1996, p. 60.

6 Liam Gearon, "Human Rights and Religion" in: Lindsay Jones (ed.), Encyclopedia of Religion, Second edition, vol. 6, New York 2005, p. 4178-4182.
} 
ments on the human being's position vis-à-vis the divine or in the cosmos as a whole. Nor do human rights contain any comprehensive ethical instructions on the correct lifestyle of individuals and communities, nor do they offer any symbols and rituals with which persons can assure one another their respect and solidarity above the level of rights. In a word: not even in terms of their normative claim, whose content is so explicitly limited, and which is concentrated at the level of law, can modern thinking on human rights threaten any immediate competition to religions and Weltanschauungen, or even to forms of ethos that find themselves cast in religious terms"

In what concerns the universal validity, "human rights present a structural affinity especially to those religions that likewise see themselves as universalistic, for example, Christianity, Islam, or the Baha'i religion. From this affinity, a religiously motivated engagement in favor of human rights can result; but there can also be resistances and reservations, especially when human rights are understood as being in contradiction to or in competition with a given proclamation in terms of religion or religious ethics" ${ }^{8}$ Regarding equality in freedom, human rights do not refer to how religions understand freedom, but emphasize the human dignity which must be respected only by state laws. This approach is in close contact with the French triad "liberty, equality, fraternity", referring mainly to human dignity. "The fact remains, of course, that a connection of human rights with a claim to equal freedom and participation in terms of political rights represents a relatively recent achievement, and religious communities frequently receive that connection with skepticism, if not indeed with open opposition. The recognition of human rights by religious communities can only succeed, then, when accompanied by a readiness for internal criticism and, if need be, reform, together with a willingness to communicate openly with the outside world".?

If you look very carefully at the history of creation, protection and promotion of human rights in Europe, we can find two important ideas that must be considered by all participants in interreligious and intercultural future meetings: "Human rights do not belong self-evidently to the heritage of the Christian religion: they have arisen in the breakdowns of modernity, and this - lest one succumb to a unilateral ideology of progress - partly as an answer to specific injustices in modern society. Secondly, however, human rights demonstrate an inner affinity for Christianity's human claim; a defence of the

7 Heiner Bielefeldt, "Human Rights" in: Kocku von Stuckrad (ed.), The Brill Dictionary of Religion, Volume II, E-L, Brill-Leiden-Boston 2006, p. 886.

8 Ibidem.

$9 \quad$ Ibidem, p. 887. 
underlying idea of the defence of human rights, that of the inviolable dignity of the human being, has always been a key concern of the Christian churches. A Christian commitment to human rights is therefore possible and meaningful, provided that it does not lead to an exclusivistic appeal to a religious or cultural heritage, such as an appropriation of human rights in a canon of exclusively Christian values"10.

\section{Orthodox Christian position on the issue of human rights}

In Christianity, Jesus Christ, our Savior, teaches that: "You shall love your neighbour as yourself" (Mark 12. 31). God is the Creator of all men: "When God created humankind, he made them in the likeness of God. Male and female he created them, and he blessed them and named them «Humankind» when they were created" (Genesis 5. 1). All people are created in God's image and tend to likeness with Him: "Then God said «Let us make humankind in our image, according to our likeness; and let them have dominion over the fish of the sea, and over the birds of the air, and over the cattle, and over all the wild animals of the earth, and over every creeping thing that creeps upon the earth». So God created humankind in his image, in the image of God he created them; male and female he created them" (Genesis 1. 26-27). Our Saviour Jesus Christ reinforces this idea: "Have you not read that the one who made them at the beginning made them male and female?" (Matthew 19.4).

In the Lord Jesus Christ we are recreated by God the Father: "For in him we live and move and have our beginning, as even some of your own poets have said, for we too are his offspring" (Acts 17. 28). Thus, through Him we are all reinstated in the quality of image of God: "And have clothed yourselves with the new self. Which is being renewed in knowledge according to the image of its creator" (Colossians 3. 10).

It can thus be seen that all the people on earth have the same rights, regardless of race, language or education, because they have divine origin. Human freedom comes from God who is the Holy Trinity, a communion of Persons. God is the Father of all: "Our Father in heaven, hallowed be your name" (Matthew 6. 9). The incarnate Son of God teaches us: "And call no one your father on earth, for you have one Father - the one in heaven" (Matthew 23. 9). Finally, "The God who made the world and everything in it, he who is Lord of heaven and earth, does not live in shrines made by human hands, nor is he served by human hands, as though he needed anything, since he himself gives to all mortals life and breath and all things. From one ancestor he made all nations to inhibit the whole earth, and he allotted the times of

$10 \quad$ Ibidem, p. 889. 
their existence and the boundaries of the places where they would live" (Acts 17. 24-26). Thus, God is the Father of everybody: "One God and Father of all, who is above all and through all and in all" (Ephesians 4. 6).

In the discussions that have as their theme the human rights, the important purpose is of existence on earth, and that Gods love embraces all men, because He sent His Son into the world for all of us: "And the Word became flesh and lived among us, and we have seen his glory, the glory as of the father's only son, full of grace and truth" (John 1. 14).

The greatest gift of man from God is freedom: "And you will know the truth, and the truth will make you free"; "So if the Son makes you free, you will be free indeed" (John 8. 32, 36), because: "the Lord is the Spirit, and where the Spirit of the Lord is, there is freedom" (2 Corinthians 3. 17). Christianity is the religion that emphasizes the equality among men deriving from God's immeasurable love for us: "In the renewal there is no longer Greek and Jew, circumcised and uncircumcised, barbarian, Scythian, slave and free; but Christ is all and in all" (Colossians 3. 11). In another place, St. Apostle Paul notes: "There is no longer Jew or Greek, there is no longer slave or free, there is no longer male and female; for all of you are one in Christ Jesus" (Galatians 3. 28).

Not infrequently the Orthodox Christians were accused of not understanding and not respecting human rights as they are formulated in the current statements and not putting into practice, according to the Western approach, the way these rights must be respected and protected. This attitude comes from a misunderstanding of how Orthodoxy understands man and human dignity compared to the same understanding in other Christian denominations. "Within Orthodoxy, human rights were respected and promoted on the basis of Christian ethics, without the necessity to write an official document about this. In the Orthodox Church the human person always enjoyed his/her unique value and the consequences which devolve from this quality, thus Orthodox theologies considered that the human rights issue is self-explanatory. For this reason there are not many writings on this subject. Therefore, some organizations which promote human rights, not knowing the official position of the Orthodox Church regarding this concept and criticizing its attitude related to some problems of ethical and theological nature (abortion, homosexuality, the ordination of women etc.), often accuse the Orthodox Church of encroaching upon human rights and resorting to fundamentalism". ${ }^{11}$

11 Nicolae Răzvan Stan, "The Relation between Human Dignity and Human Rights in the Orthodox Perspective" in: Studii teologice, No. 2/2008, p. 36. 
Analyzing the claims of Samuel Huntington in the book The Clash of Civilizations in which the author accuses the Orthodox tradition as guilty, in those countries where the majority are Orthodox Christians, of the inability to assimilate the principles of human rights as in the Western world. Christos Yannaras emphasized that Orthodoxy particularly emphasizes the essential difference between individual and person. Human rights, as laid down in the main international documents, beyond the fact that they make no reference to the religious values of man, refers to it as an individual and to society as the sum of all individuals. Thus, the human rights should be called "individual rights", so these cannot have validity for all people from everywhere. "However, the understanding and respect for the principle of the protection of individual rights, which was introduced by Western modernity, also exists in the Orthodox literature. The more (a society or persons, the revealing of personal uniqueness, otherness and freedom through social relations) does not invalidate or destroy the less (the legal, institutional and uniformed protection of every individual from the arbitrariness of power). The Orthodox Church acknowledges that the historical existence of such experiences as the Western Middle Ages proves that the protection of individual rights is a major success and a precious achievement. Nevertheless, we would be doing violence to historical memory and critical thought if, simultaneously, we did not recognize that, compared to the ancient Greek city or the Byzantine (and meta-Byzantine) community, the protection of human rights is a pre-political achievement. It is an undisputable achievement, but an achievement which has not yet attained (perhaps not even understood) the primordial and fundamental meaning of politics: politics as a common exercise of life «according to the truth", politics constituted around the axis of ontology (and not self-interested objectives)" 12 .

Statements about the position of the Orthodox Church towards human rights as formulated today in the main official documents can be easily extended to the other religious traditions: "Orthodox thought is not always in full agreement with everything that has been characterized from time to time as «human right». On the basic core concepts - freedom, equality, and human dignity - there is of course immediate agreement and absolute affirmation. Most of the ideas expressed about human rights are accepted by Orthodox thinking as corollaries of its own views on humanity. There are a good number of issues, however, on which Orthodox thought prefers not to take a stand, allowing them to remain open questions, within the realm of purely

12 Christos Yannaras, "Human Rights and the Orthodox Church" in: E. Clapsis, The Orthodox Churches, p. 88. 
human speculation"13. All these statements govern the relations between people in terms of their community life, especially after the separation achieved between the social and religious life. "There is also another clear difference in the way declarations and religion seek to achieve their respective aims, as well as in the profundity of those aims. Declarations seek to impose their views through legal and political forms of coercion, whereas the Christian message addresses itself to people's way of thinking and to their conscience, using persuasion and faith. Declarations basically stress outward compliance, while the Gospel insists on inner acceptance, on spiritual rebirth, and on transformation. Any attempt to consider human rights from an Orthodox point of view must therefore maintain a clear sense of the differences between these two perspectives" 14 .

From this brief analysis it is noted that human rights have been formulated and continue to be interpreted in relation to the different times of oppression in certain geographic areas, where specific rights have been ignored and violated. Currently, declarations on human rights are reinterpreted in new contexts in which we live, while opening and closing new perspectives. "In general, Orthodox thought considers the current discussion on human rights to be extremely important, but ultimately sees it as the prelude to a discussion of humanity's much more intrinsic «rights». After all the searching and all the effort to arrive at a definition of human rights, the underlying questions still remain: "Where do human rights begin, where do they end, and what is their ultimate purpose?» Declarations remain confined to descriptive legal definitions of human rights; as the same time, however, they reflect hope and express a moral judgment"15.

\section{Human rights from the perspective of Islam}

In Arabia, there is for "right" the word "haqq" (pl. "huquq") which also means "truth", the ultimate truth in Islam is known only in the holy book, Quran, and ultimately, to God (Allah), the supreme judge of all men. Allah is the one who gave the right to the people and he is what guarantees and ensures their retention. The Quran refers to the right to religion (2:256), justice and equality among people (5:8), the right to life (51:19), the right to participate in the political life of the city (42:38), the right to inheritance (4:7-9), and many other rights. However, interpretation of Qur'anic verses is different

13 Archbishop Anastaios Yannoulatos, Facing the World. Orthodox Christian on Global Concerns, Translation by Pavlos Gottfried, WCC Publications, Geneva 2003, p. 51

14 Ibidem, p. 52.

15 Ibidem, p. 57. 
depending on the position adopted regarding the issue of human rights. "One can say broadly, however, that rights in Islam are conceptualized as belonging to the individual and to the community, and the right of the community to function in harmony takes precedence over those of an individual. In addition to this major difference, some Islamic scholars (ulama) also promote a vision of gender relations built on the idea of complementarity, which refers to different but equal and complementary rights and roles for each of the genders. This differs significantly from secular and feminist emphasis on strict equivalence of gender roles" 16 .

The issue of human rights (buquq al-insan) in Islam is quite delicate, raising many questions, taking into account the fact that most modern Muslim researchers support the idea that international declarations on human rights are of Judeo-Christian origin: "The normative idea, underlying human rights, of the inviolable value of every human being finds expression in the Judeo-Christian tradition through the concept that human beings - and indeed man and woman as such - have been created after the image of God"17. At the same time, it has not yet been determined how these rights can be applied to all people regardless of the religion to which they belong. In our times, "the vast majority of Muslims and many non-Muslims argue, however, that human rights are not only compatible with Islam but integral to its core values of justice, equality, and freedom. They criticize the cultural bias of the current UN framework as placing too much emphasis on the individual and call for a deeper understanding of the rich cultural and religious heritage Islamicate societies have to contribute to the discussion" ${ }^{18}$.

The approach is not new; ever since the nineteenth century voices have risen in the Muslim world that treated topics such as political and religious freedoms. Among those who have dealt with these topics are included the Egyptian researcher Rafi al-Tahtawi Rifaa (1807-1871) and the Persian diplomat Miza Malkom Khan (1833-1908). "In the Ottoman Empire, significant reforms were initiated with the hatt-i serif (1839; noble rescript of Sultan 'Abdulmejid) and the hatt-i humayun (1856; imperial rescript, reaffirming the hatt-i serif) guaranteeing security of life, honor, and property, and a fair and public trial of individuals, and civil equality for all Ottoman subjects"19.

16 Michelle Zimney, "Human Rights" in: Juan E. Campo (ed.), Encycopledia of Islam, New York 2009, p. 314.

17 H. Bielefeld, "Human Rights", p. 887.

18 M. Zimney, "Human Rights", p. 314.

19 Ursula Günther, "Human Rights" in: Richard C. Martin (ed.), Enciclopedia of Islam and the Muslim World, Volume 1, A-L, New York, p. 318. 
Although most of the Muslim countries have signed the United Nations Charter of Human Rights of December, 10, 1948, most issues were raised in relation to Article 18 of the Universal Declaration which says: "Everyone has the right to freedom of thought, conscience and religion; this right includes the freedom to change his religion or belief, and freedom, either alone or in community with other in public or in private, to manifest his religion or belief in teaching, practice, worship and observance". Some Muslim countries have proposed the deletion of this article, while others, like Lebanon, accepted the article, being criticized by other Muslim-majority countries. The same criticisms have been raised about the formulation of the International Covenant on Civil and Political Rights and from the Declaration on the Elimination of All Forms of Intolerance and of Discrimination Based on Religion or Belief. "The conflict, then, seems clear. The articles on freedom of religion and conscience in various human rights documents appear to run afoul, at important points, of much "established» and "official» Muslim teaching about the treatment of apostates (murtadds) and protected non-Muslims (dhimmis)" 20 .

In these circumstances, the biggest problems are related to human rights documents that refer to religious freedom, taking into account that the Quran denounced those who renounce Islam for another religion. "The major historical example is the revolt of the tribes after the death of the Prophet in A.D. 632. Abu Bakr, and jurists since then, condemned secession from Islam (riddah) as doubly heinous: It is not only a violation of the compact of submission made with Allah, but it is also a breach of contract with his representatives on earth. It is, then, an offense both against God and against the state: it is both apostasy and treason. Far from having the right to become non-Muslim, the Muslim faces the death penalty as a sanction for such a charge" 21 . In our time there is an attempt to rethink and reinterpret situations where force can be used when discussing the issue of apostasy, outlining many pro and con positions, without being able to find a common voice in the Muslim world.

In 1973, with participation of all Muslim countries, the Organization of the Islamic Conference (OIC) was founded and, in 1990, introduced what was to be known in history by the name of the Cairo Declaration of Human Rights in Islam, from the desire to identify the link between human rights elements, as seen from the point of view of Islamic teachings and elements of international law. This declaration deals with themes that relate to education, equal-

20 Charles Amjad-Ali, “Text and Interpretation: Superfluity on Issues of Human Rights" in: Tarek Mitri (ed.), Religion and Human Rights, p. 31.

21 Ibidem, p. 35. 
ity before the law, marriages, proprietary right to freedom in all its forms, freedom of expression to its own opinions, all seen in relation to Islamic law. In Article 24 of the Cairo Declaration stated: "All rights and liberties cited in this Declaration are subordinate to the Islamic Sharia".

Although the Cairo Declaration has not been ratified, it continues to be regarded as an important contribution to addressing human rights in terms of Islam. Also known in the Islamic world is The Muslim Universal Declaration for Human Rights formulated by fifty Muslim thinkers and personalities under the auspices of the Muslim Council in London and it was declared in a meeting held at UNESCO headquarters in Paris on 19 September 1981. The rights mentioned in this manifest are: the right to life, the right to freedom, the right to equality, the right to justice, the right of the individual to a fair trial, the right to protection from oppression of authority, the right to protection from torture, the right of the individual to protection of his honour and reputation, the right to asylum, the rights of minorities, the right to participation in public life, the right to freedom of thinking, belief and expression, the right to religious freedom, the right to engage in missionary work, economic rights, the right of ownership, the rights and duties of the worker, the right of the individual to self-sufficiency, the right to set up a family, the rights of the wife, the right to education, the right of the individual to protect his private possessions, the right to mobility and residence ${ }^{22}$.

Another important statement in Islam is Human Rights in Islam, which, although it was made in 1980, was only published by one of the authors in 1992 in Damascus, being the nearest to the Universal Declaration of Human Rights. The main points of this statement are: basic rights, political rights, family rights, the right of citizenship and nationality, the right to education, the right to work and social security, the right to earn a living, to benefits and to literary ownership, the right to a trial, the right to mobility and to asylum, the rights and duties during war time, the sanctity of the dead and the limits and interpretation of this legitimate document. ${ }^{23}$

The main difference between this statement and the one of human rights globally known is that the UN Charter does not use or support religious concepts in its content. One cannot speak of the same thing when it comes to the formulations in the Muslim world, the divine law stands in the statements on human rights. "Article 24 of the Cairo Declaration subordinates all rights and freedoms to shari'a (Islamic law), without clarifying the

22 Ridwän Al-Sayyid, "Human Rights" in: Tarek Mitri (ed.), Religion and Human Rights, p. 47.

23 Ibidem, p. 47-48. 
limits or questioning the area of conflict between civil and political rights, enacted in the constitution and international conventions on human rights, and the obligations that arise according to shari' $a$. The sensitive points lay in the area of equality, particularly gender equality, as well as in the fields of art and science" ${ }^{24}$. In this respect, in Islam is made a difference between equality concerning the dignity and the equality towards the rights. If all people regardless of sex, race or creed, are equal in terms of dignity, the same cannot be said in the terms of rights. It is the case of women and non-Muslims believers comparatively with Muslim men. "Furthermore, the right of religious freedom is extremely limited for Muslims, since apostasy entails numerous civil law sanctions - such as the loss of the entitlement to inherit or the loss of the right to remain married to a Muslim partner - and even carries the possibility of a death sentence" 25 .

In Muslim-majority states ${ }^{26}$ the citizens are divided into Muslims and non-Muslims, the first having responsibilities for the proper management of the state, non-Muslims cannot occupy political positions. They are divided according to Muslim law, into three categories: those who become the subject of a treaty of acceptance, those who live in these countries as a result of wars, and those who live here in other forms, certain rights being respected according with these three categories, with the freedom to manifest their own religion ${ }^{27}$. However, history has recorded many instances where human rights were not respected for the minority belonging to other religions. "In modern times the whole concept of citizenship based on the notion of one's religion is to be re-thought. In medieval times such concepts might have been permissible as there was no concept of nation-state then. In the modern nation-state there is no question of discrimination between citizens on the basis of religion. This practice, it must be noted, is not against the teaching or the spirit of the Quran. Composite nationalism, on the basis of common citizenship must be accepted. The Jami'at al-ulama-i-Hind also accepted this notion of composite nationalism and common citizenship during the freedom struggle. All citizens, similarly, should be treated equally in an Islamic state too. Neither should there be any discriminatory taxes nor different categories of

\footnotetext{
24 U. Günther, "Human Rights", p. 318.

25 Ibidem.
}

26 We have not proposed in this study to analyse the different political systems in the Islamic world (as it found in countries such as Saudi Arabia, Turkey, Egypt, Tunisia, Iraq, Syria, Libya, Algeria, etc.). This theme, very relevant in our times, requires more attention and analysis from the researchers in the related fields (history of religions, political science, sociology, etc.). 27 Hafeez-Ur-Rehman Chaundry, "Religion and Human Rights" in: Tarek Mitri (ed.), Religion and Human Rights, pp. 20-21. 
citizenship on the basis of religion. In the modern nation-state, citizenship is a political and not a religious category. Though everyone will have one's own religion to follow (which would include method of worshipping, rituals and cultural practices), all will enjoy equal rights and privileges as citizens and would not be subject to any discriminatory practice on the basis of religion. Religion and citizenship should be separated from each other" ${ }^{28}$.

A special situation which differs according to each territory is where Muslims are minorities in the territories where the most are followers of other religions, as is the case in India, America, Canada, England, Burma, Philippines, Bosnia-Herzegovina etc. In these areas the situation is complex and varies from case to case, but each time the religious freedom of each individual must be respected separately. "Also, the Quranic concept of rabubiyyah (provision for basic and other needs for gradual perfection of life) is not exclusive for Muslims. It is universal. Though religions may differ, humanity remains a common denominator. Some religious leaders like Maulana Azad even maintain that in essence din (moral law) is the same in Shari'ah (outward forms of worship and the other rituals) which differ from people to people and what matters is din and it being common to all must enjoy equal rights without any discrimination" 29 .

Lately, many Muslim societies that defend human rights struggle for reviewing the Cairo Declaration in order to align it with the prescription of the UN Declaration. However, we cannot say that there was a radical change in the vision of human rights, because not all Muslim territories desire the total detachment the old approach and to assimilate the way in which human rights are formulated in the West. Finally, "the actual situation in Muslim countries reflects the complex social and political balance of power, inclusive of the monopoly of definition and interpretation, rather than the relation between Islam and human rights. This explains the existing gap between ideals and practice". ${ }^{30}$ In most cases, when human rights are not respected, it uses the authority of Islamic law (shari ${ }^{\prime}$ ) ) which is often arbitrarily interpreted in order to justify actions that are against the people. In most cases the human rights which are violated are freedom of religion, protection of minorities, and women's rights or gender equality. All this is based on the contradiction between the United Nations Declaration of Human Rights and the Principles of shari'a. "On the one hand, civil and political rights are accorded to any

28 Aahgar Aliengineer, "Islam and the Rights of Non-Muslim Minorities" in: Tarek Mitri (ed.), Religion and Human Rights, p. 77.

29 Ibidem.

30 U. Günther, "Human Rights", p. 319. 
citizen in Muslim countries by the constitution and the UN Charter but, on the other hand, the necessity of conformity with the norms and prescriptions of shari'a are religiously legitimized. However, this discourse rarely includes the intense and diverse debates that are going on simultaneously within the Muslim world regarding the limits and possibilities of the adoption of human rights within the Islamic context" ${ }^{31}$. The state can intervene only in areas not covered by Islamic law, or in a situation where a particular religious prescription is ambiguous. "Even though many Muslim countries partially or completely abandoned islamic law, they could not completely remove it" 32 .

If one looks carefully at how the problem of human rights is dealt with in the Muslim world it is observed that there are two camps that promote opposing views, although both are based on the relation that exists between Islamic law and human rights as formulated in international declarations. "Nevertheless, we must admit that the modern Muslim jurists transformed, under the pressure of domestic problems and the Western model, human rights issues to issues noted by the public. They have reached solutions for issues such as equality before the law, meaning of citizenship and they have even bypassed the medieval concept of Dār al-Islām and Dār al-Harb. However, Muslim strictness that loomed large during the epoch of the "Awakening» in the past decades prevented a brave consideration of the rest of the issues such as the distinction between men and women, the issues of the kind of punishment stipulated in Shari' ${ }^{\prime}$ h (hudūd) and the problem of apostasy. In reality, it is possible to distinguish between problems that are historical and those supported by texts from Sharíah. It is also clear that many restrictions have come about as a result of specific historical or legal circumstances, and many modern jurists say that rulings branching off from these circumstances are abolished in accordance with the juristic rule which says that rulings change with time. Rulings based on Quranic or Prophetic texts however have been confirmed by ancient customs and traditions and seem to be difficult to solve" 33 .

The two positions created in the Islamic world about human rights are represented by the secular approach and one that is ethical. The first view was supported by scholars such as the Egyptian Ali Abd al-Raziq (1888-1966), which supports the idea that in the Quran specific forms of government are

\footnotetext{
31 Ibidem.

32 Nicolae Achimescu, "Islamul între Europa și drepturile omului" in: N. R. Stan (ed.), Biserica Ortodoxă și drepturile omului: Paradigme, fundamente, implicații, București 2010, p. 327.

33 R. Al-Sayyid, "Human Rights", p. 50.
} 
not prescribed, so a regime in which religion and politics should be separate it is not necessarily un-Islamic. This view was supported by other Muslim scholars, among which the Egyptian jurist Muhammad Sa'id al-'Ashmawi and the Syrian sociologist Burhan Ghaliyun. On the other hand, there are those who say otherwise, based on the idea that man is responsible to God, which implies a moral attitude as basis of society, according to the Islamic law. These two sides have awakened many interpretations about what is Quran as the last revelation. Thus, the Muslim holy book was used in the two interpretations of human rights, in both camps. "The public discussion of human rights in Islam has traditionally taken the form of legalistic debates between ulama as to the meaning of the Quran"34.

Over the past few years, not often human rights have been violated in the Muslim countries, as happened in July 1998 when Ruholla Rohani, a member of the Baha'i religious community, was executed in the Islamic Republic of Iran. Other members of the Baha'i community were executed on charges of apostasy from Islam. "It is not only members of religious minorities who currently suffer repression in Iran. That country's victims of the violation of human rights include authors critical of religion, and conservative Shiite clergy not in accord with the concrete instrumentality of Shiite Islam as the religion of the state" ${ }^{35}$

A crucial moment in terms of how the Muslim world was characterized was the events of September 11, 2001 following the attacks on the World Trade Centre in New York, USA. The discrimination against Muslims in the U.S. has spread across Europe after these events; the issue of human rights has become one of actuality, being present on the agendas of all meetings that have interfaith issues. Also organizations promoting human rights multiplied in every world religion. Not to be overlooked is the fact that in 2004, the Iranian human rights activist Ebadi Shrine (b. 1947) received the Nobel Peace Prize in recognition of his merits in promoting human rights. Among other Muslim leaders fighting for promoting human rights in the Islamic world are Abdullahi An-Na im (Sudan), Abd al-Karim Soroush (Iran) Fatima Mernissi (Marocco), Khaled Abou El Fadl (USA), Taslima Nasrin (Bangladesh), Muhammad Arkoun (Algeria), Mohamed Talbi, Said al-Ashmawi and Nasr Hamid Abu Zaid. "The intra-Islamic debate on human rights demonstrates that thinking on human rights is also developing its effects in «extra-occidental» religions or cultures, and not only as the reception of Western approaches, but also as a reevaluation of the actual sources of the

34 M. Zimney, "Human Rights", p. 314.

35 H. Bielefeld, "Human Rights", p. 884. 
traditions of these religions or cultures. If it is possible for human beings of distinct religious orientations to recognize, so to speak, humane motifs of their own tradition in modern human rights, then this process can foster the development of a universal consciousness of human rights - presuming, of course, that unilateral religious or cultural «heritage claims» to the idea of human rights are definitively sidelined"36.

\section{Conclusions}

From the preceding discussion it is clear that the human rights issue is quite sensitive, especially after the latest political, economic and social events that have shaken the world in which we live. After the period of time that the proclamation and recognition of global human rights were made as contained in the various international documents, it was passed into a new phase where the followers of different religions should work together for human dignity and human rights. "Muslims and Christians are called to cooperate in preventing the misuse of religious sentiments in the violation of human rights, both of individuals and communities. They need to unite in efforts against divisions and seditions that use the rights of minorities as a pretext for foreign intervention and hegemony. Muslims and Christians committed to dialogue have a special responsibility to elaborate a common approach that finds the proper balance between the human rights of the individual, and that of the community, and must be seen to be in harmony with a religious understanding of obligations. They may have to consider the setting up of a structure of collaboration that pays special attention to human rights violations which impact negatively on Christian-Muslim relations, ensuring that the defense of those rights is not confined to the dimensions of the solidarity restricted to victims from one's own religious community". ${ }^{37}$ The proliferation of bilateral meetings in which are involved representatives of Christianity and Islam is further evidence of the current concerns of people with common interests to find a solution for the protection and promotion of human dignity and human rights worldwide, regardless of the religion to which they belong ${ }^{38}$.

36 Ibidem, p. 891.

37 Yousef Al Hassan, "Dialogue in the Better Way" in: Tarek Mitri (ed.), Religion and Human Rights, p. 95.

38 The issue of equality between men and women in the two monotheistic religions is an issue too complex to be treated in this study. We stopped only tangentially on it and then followed to analyse it in a research exclusively dedicated. However we mention here some works: in the Orthodox world, the issue of equality between men and women is focused especially on the issue of women's priesthood. Elisabeth Behr-Sigel, Kallistos Ware, The Ordination of Women in the Orthodox Church, WCC Publications, Geneva 2000; in the Islamic world, the 
Regarding the involvement of the Orthodox Churches in social life and in promoting and defending human rights it should be emphasized that: "the Orthodox Church plays an important role here with the other Christian churches and non-Christian religions for finding and applying common solutions towards the realization of a better life for everybody. It is clear that universal rights can only be truly universal if they are accepted and respected by all people. It is only possible to reach such agreement through dialogue, being mindful of the fact that political institutions and religious bodies each use different kinds of language in the human rights discourse. (...) Thus, the common struggle for the promotion of human rights must become a point of meeting for all religions for the development of peace, love and respect between people and countries, for a building of a more ethical and just world. In this regard, from the Orthodox point of view, it is not possible to think of a future for all humanity and for the world without respect for what the concept of human rights presupposes" 39 .

\section{Acknowledgment:}

"This work was partially supported by the grant number 5C/27.01.2014, awarded in the internal grant competition of the University of Craiova”.

literature dealing with the ratio between men and women is growing. Haifaa A. Jawad, The Rights of Women in Islam. An Authentic Approach, London 1998; in Romanian: Harun Yahya, Fecioara Maria - o femeie musulmană exemplară, Bucureşti 2007; idem, Femeia în islam, Bucureşti, 2013.

39 N. R. Stan, “The Relation between”, p. 68. 